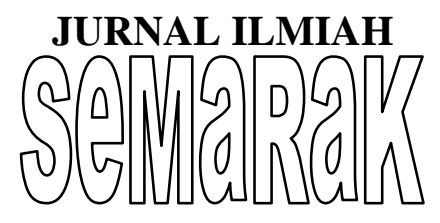

P-ISSN 2615-6849

Jurnal Semarak, Vol. 1,No.1,Februari 2018 , Hal (92-107)

@ Prodi Manajemen Fakultas Ekonomi Universitas Pamulang

\title{
PENGARUH DISIPLIN KERJA TERHADAP PRODUKTIVITAS KERJA KARYAWAN PADA PT. TELKOM AKSESS LEGOK
}

\author{
Reni Hindriari \\ Dosen Fakultas Ekonomi Universitas Pamulang \\ Email : reni.hindriari@gmail.com
}

\begin{abstract}
Abstrak
Penelitian ini dilakukan dengan tujuan untuk mengetahui Disiplin Kerja Karyawan, Produktivitas Kerja Karyawan dan Pengaruh Displin kerja Terhadap Produktivitas Kerja Karyawan PT Telkom Aksess Legok.Penelitian ini menggunakan metode assosiatif kuantitatif analisis. Populasi dalam penelitian adalah seluruh karyawan PT Telkom Aksess Legok yang berjumlah 65 orang dengan menggunakan sampel jenuh. Hasil Penelitian $\mathrm{Y}=$ $7,733+0,827 \mathrm{X}$, artinya jika disiplin kerja ditingkatkan 1 satuan maka produktivitas kerja akan meningkat 0,827 satuan dan sebaliknya. Koefisien korelasi sederhana $r=0,777$ artinya berarti kuat. Koefisien determinasi $\mathrm{KD}=60,3 \%$ artinya $60,3 \%$ disiplin kerja berkontribusi terhadap produktivitas kerja karyawan dan sisanya 39,7 \%oleh factor lainnya. Uji Signifikan $t_{\text {hitung }} 9,788 \geq t_{\text {tabel }} 1,669$, maka menunjukkan hasil yang signifikan atau dengan kata lain $t_{\text {hitung }} \geq t_{\text {tabel }}$ yaitu Ho ditolak dan Ha diterima yang berarti bahwa terdapat pengaruh yang signifikan antara disiplin kerja terhadap produktivitas kerja karyawan pada PT Telkom Akses Legok.
\end{abstract}

\section{Kata Kunci :Disiplin Kerja dan Produktivitas Kerja.}

\begin{abstract}
This research was conducted with the aim to know Employee Discipline, Employee Productivity and Influence Displin work on Employee Productivity PT Telkom Aksess Legok.This research uses quantitative assosiative. The population in the study were all employees of PT Telkom Aksess Legok which amounted to 65 people using saturated samples. The questionnaires technique is done by distributing questionnaires to 65 employees to collect data by asking every employee to answer every statement contained in questionnaire given, observation technique by doing direct observation to employees who are working.

Research result $\mathrm{Y}=7,733+0,827 \mathrm{X}$, meaning that if work discipline is increased 1 unit then work productivity will increase 0,827 unit and vice versa. Simple correlation coefficient $r=$ 0.777 means strong. Coefficient of determination $\mathrm{KD}=60.3 \%$ means $60.3 \%$ work discipline contribute to employee work productivity and the remaining $39.7 \%$ by other factors. Significant Test $9,788 \geq 1.669$, then show significant results or in other words $\geq$ that is Ho rejected and $\mathrm{Ha}$ accepted which means that there is a significant influence between work discipline on employee productivity at PT Telkom Access Legok.
\end{abstract}

Keywords: Work Discipline and Work Productivity. 


\section{A. Pendahuluan}

Hal yang paling dasar dalam kedisiplinan karyawan adalah manajemen waktu, dalam hal ini yaitu jam kerja. Apabila waktu tersebut sering dilanggar, dapat dikatakan bahwa para karyawan menjadi tidak disiplin sehingga mengakibatkan penurunan produktivitas dan kualitas kerja karyawan. Hal ini tentu saja berdampak pada pemborosan waktu sehingga biaya yang dikeluarkan pun menjadi berlipat-lipat dari biaya yang telah dianggarkan.

Menurut

(2010:128)

produktivitas merupakan perbandingan antara keluaran dan masukan serta mengutarakan cara pemanfaatan baik terhadap sumber-sumber dalam memproduksi suatu barang atau jasa. Dari pemahaman diatas dapat dikatakan bahwa produktivitas menyentuh berbagai aspek dalam diri manusia seperti sikap, mental, etika dan keahlian sehingga dapat dijadikan sebagai pendorong dalam meningkatkan mutu untuk menjadi lebih baik setiap harinya. Dari pengamatan yang penulis lakukan diperoleh dari informasi bahwa adanya indikasi rendahnya disiplin kerja karyawan pada PT TELKOM sehingga dapat mengakibatkan produktivitas kerja menurun. Hal ini dilihat dari masalah-masalah sebagai berikut: (1) Kurangnya upaya yang dilakukan pimpinan untuk meningkatkan disiplin kerja karyawan. (2) Jam kerja yang belum dipatuhi oleh karyawan, hal ini masih terlihat yang datang tidak tepat waktu ke kantor jam masuk kerja pukul 08.00 WIB sementara karyawan ada yang datang pada pukul 08.30 WIB. (3) Kurangnya tanggung jawab dalam melakukan pekerjaan, tanggung jawab yang kurang dari para karyawan PT TELKOM dalam melakukan pekerjaan yang telah diberikan serta pekerjaan yang diberikan tidak selesai pada waktu yang telah ditentukan. Masalah diatas apabila dibiarkan maka akan mengakibatkan rendahnya disiplin kerja karyawan serta mengakibatkan produktivitas kerja menurun sehingga tujuan dari perusahaan sulit untuk dicapai.

Disiplin karyawan yang baik akan mempercepat pencapaian tujuan perusahaan, sedangkan disiplin yang kurang baik akan menjadi penghalang dan memperlambat pencapaian tujuan perusahaan. Kegiatan pendisiplinan yang dilaksanakan untuk mendorong para karyawan agar mengikuti berbagai standar dan aturan, sehingga penyelewanganpenyelewengan dapat dicegah. Dari penjelasan diatas dapat disimpulkan bahwa produktivitas kerja karyawan dalam suatu perusahaan sangat dipengaruhi oleh disiplin karyawan. Apabila diantara karyawan sudah tidak menghiraukan kedisiplinan kerja, maka dapat dipastikan produktivitas kerja akan menurun. Padahal untuk mendapatkan produktivitas kerja sangat diperlukan kedisiplinan dari para karyawan, maka penulis tertarik untuk meneliti lebih jauh lagi tentang kedisiplinan kerja terhadap kelancaran operasional kerja pada PT. Telkom Tbk, dalam penulisan penelitian ini, dengan judul "PENGARUH DISIPLIN KERJA TERHADAP PRODUKTIVITAS KERJA KARYAWAN PADA PT. TELKOM AKSES LEGOK".

\section{B. Perumusan Masalah}

Berdasarkan uraian latar belakang, identifikasi masalah serta pembatasan masalah, maka dapat dirumuskan masalah yang akan dibahas pada penelitian ini adalah :

1. Bagaimana disiplin kerja karyawan pada PT Telkom Akses Legok?

2. Bagaimana tingkat produktivitas kerja karyawan pada PT Telkom Akses Legok? 


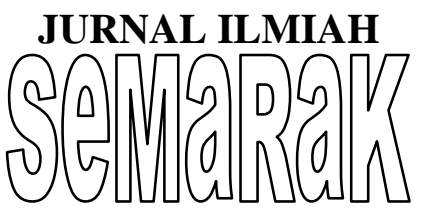

3. Seberapa besar pengaruh antara Disiplin kerja terhadap produktivitas kerja karyawan di PT Telkom Akses Legok?

\section{Kerangka Berpikir}

Kerangka berfikir penelitian ini dapat digambarkan sebagai berikut :

\begin{tabular}{|l|l|}
\hline \multicolumn{1}{|c|}{ Disiplin Kerja } & \multicolumn{1}{|c|}{ Produktivitas Kerja } \\
1. Tujuan dan & \\
Kemampuan & \\
2. Teladan Pemimpin & \\
3. Balas jasa & \\
4. Keadilan & 1. Kemampuan \\
5. Waskat & 2. Meningkatkan hasil \\
6. Sanksi hukuman & yang di capai \\
7. Ketegasan & 3. Semangat kerja \\
8. Hubungan & 4. Pengembangan diri \\
kemanusiaan & 5. Mutu \\
Malayu & 6. Efisiensi \\
& \\
\hline
\end{tabular}

\section{Landasan Teori \\ 1. Disiplin Kerja}

Menurut Siagian (2009:305) disiplin adalah tindakan manajemen untuk mendorong para anggota perusahaan memenuhi tuntunan berbagai ketentuan tersebut. Pendisiplinan karyawan adalah suatu bentuk pelatihan dalam upaya memperbaiki dan membentuk pengetahuan, sikap, dan perilaku karyawan sehingga para karyawan tersebut dapat secara sukarela berusaha bekerja secara kooperatif dengan para karyawan lain serta mampu meningkatkan prestasi kerjanya.

Melayu S.P Hasibuan (2012:193) mengatakan bahwa disiplin adalah kesadaran dan kesediaan seseorang mentaati semua peraturan perusahaan dan norma norma sosial yang berlaku. Kesadaran itu sendiri adalah sikap seseorang yang secara suka rela mentaati semua peraturan dan sadar akan tugas tanggung jawabnya sehingga akan mematuhi dan mentaati segala norma peraturan yang berlaku di organisasi sedangkan kesediaan adalah suatu sikap tingkah laku dan perbuatan seseorang yang sesuai dengan peraturan perusahaan ik yang tertulis maupun yang tidak..

Disiplin merupakan faktor utama yang mempengaruhi produktivitas perlu adanya disipliniasi, yaitu menciptakan keadaan suatu lingkungan kerja yang tertib, berdaya guna dan berhasil guna melaluisuatu sistem pengaturan yang tepat. Sementara disiplin itu sendiri adalah ketaatan dalam aturan.

\section{Produktivitas kerja}

Produktivitas secara umum diartikan sebagai hubungan antara keluaran (barangbarang atau jasa) dengan masukan (tenaga kerja, bahan, uang). Produktivitas adalah ukuran efisiensi produktif, suatu perbandingan antara hasil keluaran dan masukan. Masukan sering dibatasi dengan tenaga kerja, sedangkan keluaran diukut dalam kesatuan fisik, bentuk dan nilai.

Sumber daya manusia merupakan elemen yang paling strategis dalam perusahaan, harus diakui dan diterima manajemen. Peningkatan produktivitas kerja hanya mungkin dilakukan oleh manusia. Sebaliknya, sumber daya manusia pula yang dapat menjadi penyebab terjadinya pemborosan dan inefisiensi dalam berbagai bentuknya (Siagian,2002). Karena itu memberikan perhatian kepada unsur manusia merupakan salah satu tuntutan dalam keseluruhan upaya peningkatan produktivitas kerja.

Menurut Hasibuan (2009:125) "Produktivitas mengandung sikap mental 
yang selalu berpandangan bahwa kehidupan hari ini harus lebih baik dari kemarindan esok lebih baik dari hari ini". Produktivitas mengikutsertakan pendayagunaan secara terpadu sumber daya manusia dan ketrampilan, barang modal teknologi, manajemen, informasi, energi dan sumber-sumber lain menuju kepada pengembangan dan peningkatan standar hidup untuk seluruh masyarakat, melalui pengertian produktivitas kerja.

\section{Metodologi Penelitian}

Sifat penelitian ini adalah assosiatif. Menurut Sugiyono (2008:5) penelitian assosiatif merupakan penelitian yang bertujuan untuk mengetahui hubungan antara dua variabel atau lebih. Dimana hubungan antara variabel dalam penelitian akan di analisis dengan menggunakan statistika yang relevan atas data tersebut untuk menguji hipotesis

\section{Populasi Dan Sampel}

Menurut Sugiyono (2011:8), populasi merupakan wilayah generalisasi yang terdiri atas obyek/subyek yang mempunyai

\section{Hasil Pembahasan}

\section{Disiplin Kerja Pada PT Telkom Akses Legok}

a. Uji Validitas Variabel Disiplin Kerja (X)

Uji validitas digunakan untuk menguji pertanyaan maupun pernyataan pada kuesioner yang disebar untuk mengetahui valid atau tidaknya. Perhitungannya dengan cara membandingkan nilai $t_{\text {hitung }}$ dengan $t_{\text {tabel }}$ dengan taraf signifikan (kesalahan) 5\%. Bila $t_{\text {hitung }}$ lebih besar dari $\mathrm{t}_{\text {tabel, maka butir pertanyaan atau }}$ pernyataan tersebut dikatakan valid.Berdasarkan hasil penelitian yang kualitas dan karakteristik tertentu yang ditetapkan oleh penelitian untuk di pelajari dan kemudian ditarik kesimpulannya. Populasi dalam penelitian ini adalah seluruh karyawan PT. Telkom Akses Legok Karawaci sebanyak 65 orang karyawan.

Melihat bahwa populasi tersebut kurang dari 100 karyawan dan hanya berjumlah 65 karyawan maka penulis mengambil seluruh jumlah populasi untuk dijadikan sampel, dan menggunakan teknik sampling jenuh dalam menentukan sampel penelitian ini. Menurut Sugiyono (2011:85), metode sampling jenuh adalah metode pengumpulan sampel bila semua anggota populasi digunakan sebagai sampel. Istilah lain sampel jenuh adalah sensus dimana semua anggota populasi dijadikan sampel karena jumlah karyawan PT. Telkom Akses Legok Karawaci berjumlah 65 karyawan

\section{E. Analisis Hasil Penelitian dan Pembahasan}

telah penulis lakukan, disiplin kerja pada PT Telkom Aksess Legok sudah sangat baik.Hal ini dibuktikan dengan hasil perhitungan pengolahan kuesioner yang telah disebarkan kepada responden yang menyatakan bahwa seluruh butir pernyataan variabel disiplin dinyatakan "VALID" atau $r_{\text {hitung }}>r_{\text {tabel. }}$.

Untuk menguji validitas pernyataan dalam kuesioner pada penelitian ini menggunakan rumus dan tabel sebagai berikut:

Tabel 4.8 Perhitungan Analisis Variabel Disiplin Kerja (X) Contoh butir pernyataan No.1

\begin{tabular}{|l|l|l|l|l|l|}
\hline No. & $\mathbf{X i}$ & $\mathbf{X t}$ & $\mathbf{X i}^{2}$ & $\mathbf{X t}^{2}$ & $\mathbf{X i X t}$ \\
\hline 1 & 5 & 49 & 25 & 2401 & 245 \\
\hline 2 & 4 & 43 & 16 & 1849 & 172 \\
\hline
\end{tabular}


JURNAL ILMIAH

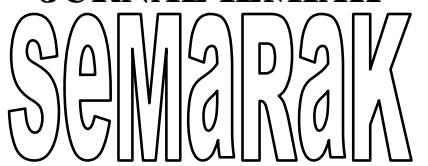

P-ISSN 2615-6849

Jurnal Semarak,Vol. 1,No.1,Februari 2018 , Hal (92-107)

@ Prodi Manajemen Fakultas Ekonomi Universitas Pamulang

\begin{tabular}{|l|l|l|l|l|l|}
\hline $\mathbf{N o .}$ & $\mathbf{X i}$ & $\mathbf{X t}$ & $\mathbf{X i}^{\mathbf{2}}$ & $\mathbf{X t}^{2}$ & $\mathbf{X i X t}$ \\
\hline 3 & 4 & 44 & 16 & 1936 & 176 \\
\hline 4 & 3 & 36 & 9 & 1296 & 108 \\
\hline 5 & 5 & 42 & 25 & 1764 & 210 \\
\hline 6 & 5 & 43 & 25 & 1849 & 215 \\
\hline 7 & 4 & 47 & 16 & 2209 & 188 \\
\hline 8 & 2 & 35 & 4 & 1225 & 70 \\
\hline 9 & 4 & 39 & 16 & 1521 & 156 \\
\hline 10 & 4 & 42 & 16 & 1764 & 168 \\
\hline 11 & 4 & 42 & 16 & 1764 & 168 \\
\hline 12 & 5 & 42 & 25 & 1764 & 210 \\
\hline 13 & 4 & 42 & 16 & 1764 & 168 \\
\hline 14 & 4 & 39 & 16 & 1521 & 156 \\
\hline 15 & 2 & 33 & 4 & 1089 & 66 \\
\hline 16 & 5 & 50 & 25 & 2500 & 250 \\
\hline 17 & 2 & 35 & 4 & 1225 & 70 \\
\hline 18 & 4 & 38 & 16 & 1444 & 152 \\
\hline 19 & 4 & 38 & 16 & 1444 & 152 \\
\hline 20 & 4 & 38 & 16 & 1444 & 152 \\
\hline 21 & 3 & 38 & 9 & 1444 & 114 \\
\hline 22 & 5 & 44 & 25 & 1936 & 220 \\
\hline 23 & 4 & 41 & 16 & 1681 & 164 \\
\hline 24 & 4 & 40 & 16 & 1600 & 160 \\
\hline 25 & 2 & 35 & 4 & 1225 & 70 \\
\hline 26 & 4 & 37 & 16 & 1369 & 148 \\
\hline 27 & 4 & 48 & 16 & 2304 & 192 \\
\hline 28 & 4 & 40 & 16 & 1600 & 160 \\
\hline 29 & 5 & 41 & 25 & 1681 & 205 \\
\hline 30 & 4 & 46 & 16 & 2116 & 184 \\
\hline 31 & 4 & 41 & 16 & 1681 & 164 \\
\hline 32 & 4 & 40 & 16 & 1600 & 160 \\
\hline 33 & 3 & 40 & 9 & 1600 & 120 \\
\hline 34 & 5 & 41 & 25 & 1681 & 205 \\
\hline 35 & 4 & 39 & 16 & 1521 & 156 \\
\hline 36 & 5 & 42 & 25 & 1764 & 210 \\
\hline 37 & 4 & 41 & 16 & 1681 & 164 \\
\hline 38 & 5 & 50 & 25 & 2500 & 250 \\
\hline 39 & 4 & 45 & 16 & 2025 & 180 \\
\hline 40 & 4 & 45 & 16 & 2025 & 180 \\
\hline 41 & 4 & 45 & 16 & 2025 & 180 \\
\hline & & & & & \\
\hline
\end{tabular}


Jurnal Semarak,Vol. 1,No.1,Februari 2018 , Hal (92-107)

@Prodi Manajemen Fakultas Ekonomi Universitas Pamulang

\begin{tabular}{|l|l|l|l|l|l|}
\hline No. & $\mathbf{X i}$ & $\mathbf{X t}$ & $\mathbf{X i}^{\mathbf{2}}$ & $\mathbf{X t}^{\mathbf{2}}$ & $\mathbf{X i X t}$ \\
\hline 42 & 4 & 45 & 16 & 2025 & 180 \\
\hline 43 & 5 & 46 & 25 & 2116 & 230 \\
\hline 44 & 4 & 38 & 16 & 1444 & 152 \\
\hline 45 & 4 & 41 & 16 & 1681 & 164 \\
\hline 46 & 5 & 47 & 25 & 2209 & 235 \\
\hline 47 & 2 & 36 & 4 & 1296 & 72 \\
\hline 48 & 4 & 44 & 16 & 1936 & 176 \\
\hline 49 & 5 & 37 & 25 & 1369 & 185 \\
\hline 50 & 5 & 44 & 25 & 1936 & 220 \\
\hline 51 & 5 & 46 & 25 & 2116 & 230 \\
\hline 52 & 4 & 38 & 16 & 1444 & 152 \\
\hline 53 & 5 & 47 & 25 & 2209 & 235 \\
\hline 54 & 4 & 40 & 16 & 1600 & 160 \\
\hline 55 & 3 & 33 & 9 & 1089 & 99 \\
\hline 56 & 3 & 40 & 9 & 1600 & 120 \\
\hline 57 & 4 & 36 & 16 & 1296 & 144 \\
\hline 58 & 5 & 47 & 25 & 2209 & 235 \\
\hline 59 & 4 & 41 & 16 & 1681 & 164 \\
\hline 60 & 4 & 40 & 16 & 1600 & 160 \\
\hline 61 & 4 & 40 & 16 & 1600 & 160 \\
\hline 62 & 4 & 28 & 16 & 784 & 112 \\
\hline 63 & 4 & 44 & 16 & 1936 & 176 \\
\hline 64 & 4 & 39 & 16 & 1521 & 156 \\
\hline 65 & 4 & 39 & 16 & 1521 & 156 \\
\hline$\sum$ & 262 & 2672 & 1098 & 111050 & 10911 \\
\hline & & & & & \\
\hline
\end{tabular}

Diketahui :

$$
\begin{aligned}
& \mathrm{Xi}=262 \\
& \mathrm{Xt}=2672 \\
& \mathrm{Xi}^{2}=1098 \\
& \mathrm{Xt}^{2}=111050 \\
& \mathrm{XiXt}=10911 \\
& \mathrm{~N}=65
\end{aligned}
$$

$$
\begin{aligned}
r & =\frac{n(\Sigma x i x t)-(\Sigma x i)(\Sigma x t)}{\sqrt{\left\{n \cdot\left(\Sigma x^{2}\right)-(\Sigma x i)^{2}\right\} \cdot\left\{\mathrm{n} \cdot\left(\Sigma \mathrm{xt}^{2}\right)-(\Sigma \mathrm{xt})^{2}\right\}}} \\
& =0,624
\end{aligned}
$$

\begin{tabular}{|c|c|c|c|}
\hline $\begin{array}{l}\text { No } \\
\text { Pertanyaan }\end{array}$ & $\begin{array}{l}\text { Koefisien } \\
\text { Korelasi } \\
\text { hitung) }\end{array}$ & $\begin{array}{l}\text { Distribusi } \\
\text { (r-tabel) }\end{array}$ & Keterangan \\
\hline 1 & 0,624 & 0,24 & Valid \\
\hline 2 & 0,615 & 0,24 & Valid \\
\hline 3 & 0,725 & 0,24 & Valid \\
\hline
\end{tabular}

Berdasarkan perhitungan di atas, maka r-hitung $(0,624)>$ r-tabel $(0,24)$, berarti Perhitungan Analisis Variabel Disiplin Kerja (X) dinyatakan valid

Tabel 4.9 Rangkuman Analisis Validitas Butir Variabel Disiplin Kerja (X) 


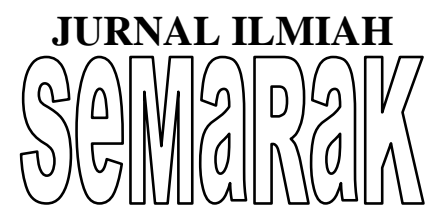

\begin{tabular}{|l|l|l|l|}
$\mathbf{4}$ & 14,8 & 0,24 & Valid \\
\hline $\mathbf{5}$ & 0,647 & 0,24 & Valid \\
\hline $\mathbf{6}$ & 0,527 & 0,24 & Valid \\
\hline $\mathbf{7}$ & 0,3 & 0,24 & Valid \\
\hline $\mathbf{8}$ & 0,494 & 0,24 & Valid \\
\hline $\mathbf{9}$ & 0,565 & 0,24 & Valid \\
\hline $\mathbf{1 0}$ & 0,535 & 0,24 & Valid \\
\hline
\end{tabular}

Dari tabel diatas dapat dilihat, bahwa dari nilai keseluruhan ( $r_{\text {hitung }}$ ) memiliki nilai yang lebih besar dari $\left(\mathrm{r}_{\text {tabel }}\right)$, atau $\left(\mathrm{r}_{\text {tabel }}\right)$ lebih besar dari 0,24. Oleh karena itu, dapat disimpulkan bahwa ke-10 butir pernyataan tersebut adalah VALID. Butir yang memiliki validitas tertinggi adalah $=0,329$ butir ke-4 yaitu 14,8 dan yang memiliki validitas terendah adalah butir ke-7 yaitu 0,30

\section{b. Uji Reliabilitas Disiplin Kerja (X)}

Suatu instrument dilakukan reliable jika nilai reliabilitas lebih besar dari rtabel.Setiap variabel diterjemahkan ke dalam 10 butir pernyataan sebagaimana terlihat pada tabel dibawah ini. Hasil perhitungan nilai varians butir adalah:

1) Menghitung Varians tiap butir dengan rumus :

$$
\begin{aligned}
& S i=\frac{\sum X i^{2}-\frac{\left(\sum X i\right)^{2}}{n}}{n} \\
& \text { Contoh butir ke } 1=\frac{1098-\frac{262^{2}}{65}}{65} \\
& =0,645
\end{aligned}
$$

5) $S i=\frac{\Sigma X i^{2}-\frac{\mathbb{Q} X D^{2}}{n}}{n}$

$$
=1,07
$$

6) $S i=\frac{\Sigma X i^{2}-\frac{\left(\Sigma X i^{z}\right.}{n}}{n}$

$$
=0,471
$$

7) $S i=\frac{\Sigma X i^{2}-\frac{\left(\Sigma X \nu^{2}\right.}{n}}{n}$

$$
=0,269
$$

8) $S i=\frac{\Sigma X i^{2}-\frac{\mathbb{C} X D^{2}}{n}}{n}$ $=0,519$

Berdasarkan perhitungan diatas dapat diketahui bahwa nilai varian butiran untuk pernyataan No.1 yang diberikan kepada responden sebesar 0,645 .

9) $S i=\frac{\Sigma X i^{2}-\frac{\left(\mathbb{E} X 0^{2}\right.}{n}}{n}$

$$
=0,403
$$

$$
\begin{aligned}
\text { 2) } & S i=\frac{\Sigma X i^{2}-\frac{\mathbb{E} X D^{2}}{n}}{n} \\
= & 0,722 \\
\text { 3) } & S i=\frac{\Sigma X i^{2}-\frac{\mathbb{E} X D^{2}}{n}}{n} \\
& =1,02 \\
\text { 4) } S i & =\frac{\Sigma X i^{2}-\frac{\mathbb{E} X D^{2}}{n}}{n}
\end{aligned}
$$

$$
\begin{aligned}
& \text { 10) } S i=\frac{\Sigma X i^{2}-\frac{\mathbb{E} X i^{2}}{n}}{n} \\
& =0,372
\end{aligned}
$$

1) Menghitung jumlah Varians skor butir pernyataan : 


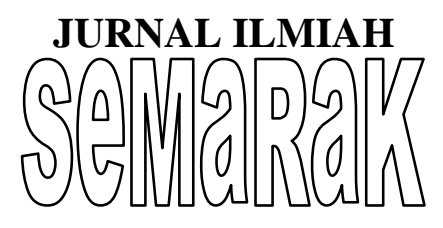

\section{P-ISSN 2615-6849}

Jurnal Semarak,Vol. 1,No.1,Februari 2018 , Hal (92-107)

@ Prodi Manajemen Fakultas Ekonomi Universitas Pamulang

$$
\begin{aligned}
\Sigma \mathrm{Si}= & \mathrm{Si} 1+\mathrm{Si} 2+\mathrm{Si} 3+ \\
& \mathrm{Si} 4+\mathrm{Si} 5+\mathrm{Si} 6+ \\
& \mathrm{Si} 7+\mathrm{Si} 8+\mathrm{Si} 9+ \\
& \mathrm{Si} 10
\end{aligned}
$$$$
\begin{array}{r}
\sum \mathrm{Si}=0,645+0,722+1,02+0,329+ \\
1,07+0,471+0,269+ \\
0,519+0,403+0,372= \\
5,82
\end{array}
$$

Tabel 4.10 Perhitungan Uji Reliabilitas Variabel Disiplin Kerja (X)

\begin{tabular}{|l|l|l|l|l|l|l|l|l|l|l|}
\hline Butir & 1 & 2 & 3 & 4 & 5 & 6 & 7 & 8 & 9 & 10 \\
\hline $\mathbf{X i}$ & 270 & 290 & 260 & 278 & 273 & 292 & 245 & 240 & 234 & 273 \\
\hline $\mathbf{X i}^{2}$ & 1148 & 13114 & 1108 & 1216 & 1181 & 1330 & 971 & 944 & 920 & 1173 \\
\hline $\mathbf{S i}$ & 0.614 & 0.31 & 1.04 & 0.415 & 0.529 & 0.28 & 0.731 & 0.889 & 1.19 & 0.406 \\
\hline
\end{tabular}

2) Mencari varians total

$$
S t=\frac{\Sigma X t^{2}-\frac{(\Sigma X t)^{2}}{n}}{n}
$$

$$
=18,619
$$

3) Mencari

Variabel

$r c a=\left(\frac{k}{k-1}\right)\left(1-\frac{\Sigma S i}{S t}\right)$

$$
=0,764
$$

Dengan demikian, karena hasil perhitungan nila $\mathrm{r}$ hitung lebih besar daripada nila $\mathrm{r}$ tabel product moment $(0,785 \geq 0,24)$
2. Produktivitas Kerja Karyawan Pada PT Telkom Aksess Legok

a. Uji Validitas Variabel Produktivitas Kerja Karyawan (Y)

Sementara itu berdasarkan hasil penelitian yang telah penulis lakukan, produktivitas kerja karyawan pada PT Telkom Aksess Legok sudah sangat baik.Hal ini dibuktikan dengan hasil perhitungan pengolahan kuesioner yang telah disebarkan kepada responden dan menyatakan bahwa seluruh butir pernyataan variabel produktivitas kerj karyawan dinyatakan "VALID". Perhitungan uji validitas untuk variabel produktivitas (Y) dapat dilihat pada tabel sebagai berikut:

Tabel 4.11 Perhitungan Analisis Variabel Produktivitas Kerja (Y) Contoh butir pernyataan No.1

\begin{tabular}{|l|l|l|l|l|l|}
\hline No. & $\mathbf{Y i}$ & $\mathbf{Y t}$ & $\mathbf{Y i}^{\mathbf{2}}$ & $\mathbf{Y t}^{\mathbf{2}}$ & $\mathbf{Y i Y t}$ \\
\hline $\mathbf{1}$ & 5 & 50 & 25 & 2500 & 250 \\
\hline $\mathbf{2}$ & 5 & 48 & 25 & 2304 & 240 \\
\hline $\mathbf{3}$ & 3 & 39 & 9 & 1521 & 117 \\
\hline $\mathbf{4}$ & 4 & 34 & 16 & 1156 & 136 \\
\hline $\mathbf{5}$ & 5 & 42 & 25 & 1764 & 210 \\
\hline $\mathbf{6}$ & 4 & 43 & 16 & 1849 & 172 \\
\hline $\mathbf{7}$ & 5 & 43 & 25 & 1849 & 215 \\
\hline $\mathbf{8}$ & 3 & 35 & 9 & 1225 & 105 \\
\hline $\mathbf{9}$ & 4 & 38 & 16 & 1444 & 152 \\
\hline $\mathbf{1 0}$ & 5 & 45 & 25 & 2025 & 225 \\
\hline $\mathbf{1 1}$ & 4 & 42 & 16 & 1764 & 168 \\
\hline $\mathbf{1 2}$ & 4 & 44 & 16 & 1936 & 176 \\
\hline $\mathbf{1 3}$ & 4 & 40 & 16 & 1600 & 160 \\
\hline $\mathbf{1 4}$ & 3 & 40 & 9 & 1600 & 120 \\
\hline
\end{tabular}


JURNAL ILMIAH

(2) 0 ilg 0,6 o) 5 U
P-ISSN 2615-6849

Jurnal Semarak,Vol. 1,No.1,Februari 2018 , Hal (92-107)

@ Prodi Manajemen Fakultas Ekonomi Universitas Pamulang

\begin{tabular}{|c|c|c|c|c|c|}
\hline No. & $\mathbf{Y i}$ & $\mathbf{Y t}$ & $\mathbf{Y i}^{2}$ & $\mathbf{Y t}^{2}$ & YiYt \\
\hline 15 & 4 & 35 & 16 & 1225 & 140 \\
\hline 16 & 5 & 50 & 25 & 2500 & 250 \\
\hline 17 & 5 & 32 & 25 & 1024 & 160 \\
\hline 18 & 4 & 34 & 16 & 1156 & 136 \\
\hline 19 & 5 & 37 & 25 & 1369 & 185 \\
\hline 20 & 4 & 37 & 16 & 1369 & 148 \\
\hline 21 & 4 & 36 & 16 & 1296 & 144 \\
\hline 22 & 4 & 38 & 16 & 1444 & 152 \\
\hline 23 & 3 & 41 & 9 & 1681 & 123 \\
\hline 24 & 4 & 39 & 16 & 1521 & 156 \\
\hline 25 & 3 & 36 & 9 & 1296 & 108 \\
\hline 26 & 4 & 35 & 16 & 1225 & 140 \\
\hline 27 & 4 & 40 & 16 & 1600 & 160 \\
\hline 28 & 4 & 41 & 16 & 1681 & 164 \\
\hline 29 & 4 & 40 & 16 & 1600 & 160 \\
\hline 30 & 4 & 41 & 16 & 1681 & 164 \\
\hline 31 & 4 & 41 & 16 & 1681 & 164 \\
\hline 32 & 4 & 41 & 16 & 1681 & 164 \\
\hline 33 & 5 & 40 & 25 & 1600 & 200 \\
\hline 34 & 4 & 44 & 16 & 1936 & 176 \\
\hline 35 & 4 & 36 & 16 & 1296 & 144 \\
\hline 36 & 5 & 42 & 25 & 1764 & 210 \\
\hline 37 & 4 & 40 & 16 & 1600 & 160 \\
\hline 38 & 5 & 50 & 25 & 2500 & 250 \\
\hline 39 & 4 & 45 & 16 & 2025 & 180 \\
\hline 40 & 5 & 46 & 25 & 2116 & 230 \\
\hline 41 & 4 & 47 & 16 & 2209 & 188 \\
\hline 42 & 4 & 44 & 16 & 1936 & 176 \\
\hline 43 & 5 & 44 & 25 & 1936 & 220 \\
\hline 44 & 4 & 38 & 16 & 1444 & 152 \\
\hline 45 & 4 & 44 & 16 & 1936 & 176 \\
\hline 46 & 4 & 45 & 16 & 2025 & 180 \\
\hline 47 & 3 & 37 & 9 & 1369 & 111 \\
\hline 48 & 4 & 43 & 16 & 1849 & 172 \\
\hline 49 & 4 & 36 & 16 & 1296 & 144 \\
\hline 50 & 3 & 43 & 9 & 1849 & 129 \\
\hline 51 & 4 & 44 & 16 & 1936 & 176 \\
\hline 52 & 3 & 33 & 9 & 1089 & 99 \\
\hline 53 & 4 & 44 & 16 & 1936 & 176 \\
\hline 54 & 4 & 41 & 16 & 1681 & 164 \\
\hline
\end{tabular}


Jurnal Semarak,Vol. 1,No.1,Februari 2018 , Hal (92-107)

@ Prodi Manajemen Fakultas Ekonomi Universitas Pamulang

\begin{tabular}{|l|l|l|l|l|l|}
\hline No. & $\mathbf{Y i}$ & $\mathbf{Y t}$ & $\mathbf{Y i}^{\mathbf{2}}$ & $\mathbf{Y t}^{\mathbf{2}}$ & $\mathbf{Y i Y t}$ \\
\hline $\mathbf{5 5}$ & 4 & 29 & 16 & 841 & 116 \\
\hline $\mathbf{5 6}$ & 3 & 39 & 9 & 1521 & 117 \\
\hline $\mathbf{5 7}$ & 5 & 44 & 25 & 1936 & 220 \\
\hline $\mathbf{5 8}$ & 5 & 47 & 25 & 2209 & 235 \\
\hline $\mathbf{5 9}$ & 5 & 50 & 25 & 2500 & 250 \\
\hline $\mathbf{6 0}$ & 4 & 40 & 16 & 1600 & 160 \\
\hline $\mathbf{6 1}$ & 5 & 42 & 25 & 1764 & 210 \\
\hline $\mathbf{6 2}$ & 4 & 34 & 16 & 1156 & 136 \\
\hline $\mathbf{6 3}$ & 5 & 43 & 25 & 1849 & 215 \\
\hline $\mathbf{6 4}$ & 5 & 39 & 25 & 1521 & 195 \\
\hline $\mathbf{6 5}$ & 4 & 45 & 16 & 2025 & 180 \\
\hline$\sum$ & 270 & 2655 & 1148 & 109817 & 11111 \\
\hline
\end{tabular}

Diketahui :

$$
\begin{aligned}
& \mathrm{Xi}=270 \\
& \mathrm{Xt}=2655 \\
& \mathrm{Xi}^{2}=1148 \\
& \mathrm{Xt}^{2}=109817 \\
& \mathrm{XiXt}=11111 \\
& \mathrm{~N}=65
\end{aligned}
$$$$
\begin{aligned}
r & =\frac{n(\Sigma x i x t)-(\Sigma x i)(\Sigma x t)}{\sqrt{\left(n \cdot\left(\Sigma x^{2}\right)-(\Sigma x i)^{2}\right\} \cdot\left\{\mathrm{n} \cdot\left(\Sigma \mathrm{xt}^{2}\right)-(\Sigma \mathrm{xt})^{2}\right\}}} \\
& =0,433
\end{aligned}
$$

Berdasarkan perhitungan di atas, maka r-hitung $(0,433)>$ r-tabel $(0,24)$, berarti Perhitungan Analisis Variabel Produktivitas (Y) dinyatakan valid.

Tabel 4.12 Rangkuman Analisis Validitas Butir Produktivitas Kerja (Y)

\begin{tabular}{|l|l|l|l|}
\hline No & $\begin{array}{l}\text { Koefisien Korelasi } \\
\text { (r-hitung) }\end{array}$ & $\begin{array}{l}\text { Distribusi } \\
\text { (r-tabel) }\end{array}$ & Keterangan \\
\hline $\mathbf{1}$ & 0,433 & 0,24 & Valid \\
\hline $\mathbf{2}$ & 0,467 & 0,24 & Valid \\
\hline $\mathbf{3}$ & 0,658 & 0,24 & Valid \\
\hline $\mathbf{4}$ & 0,669 & 0,24 & Valid \\
\hline $\mathbf{5}$ & 0,640 & 0,24 & Valid \\
\hline $\mathbf{6}$ & 0,574 & 0,24 & Valid \\
\hline $\mathbf{7}$ & 0,496 & 0,24 & Valid \\
\hline $\mathbf{8}$ & 0,560 & 0,24 & Valid \\
\hline $\mathbf{9}$ & 0,763 & 0,24 & Valid \\
\hline $\mathbf{1 0}$ & 0,850 & 0,24 & Valid \\
\hline
\end{tabular}

Dari tabel diatas dapat dilihat, bahwa dari nilai keseluruhan $\left(\mathrm{r}_{\text {hitung }}\right)$ memiliki nilai yang lebih besar dari $\left(\mathrm{r}_{\text {tabel }}\right)$, atau $\left(\mathrm{r}_{\text {tabel }}\right)$ lebih besar dari 0,24. Oleh karena itu, dapat disimpulkan bahwa ke-10 butir pernyataan tersebut adalah VALID. Butir yang memiliki validitas tertinggi adalah butir ke-4 yaitu 14,8 dan yang memiliki validitas terendah adalah butir ke-7 yaitu 0,30

\section{b. Uji Reliabilitas Produktivitas Kerja Karyawan (Y)}


Suatu instrument dilakukan reliabel jika nilai reliabilitas lebih besar dari rtabel.Setiap variabel diterjemahkan ke dalam 10 butir pernyataan sebagaimana terlihat pada tabel dibawah ini. Hasil perhitungan nilai varians butir adalah:

$$
\begin{aligned}
& \text { 1) } \begin{array}{c}
\text { Menghitung Varians tiap } \\
\text { butir dengan rumus : }
\end{array} \\
& S i=\frac{\sum Y i^{2}-\frac{(\Sigma Y i)^{2}}{n}}{n} \\
& \frac{\begin{array}{c}
\text { Contoh butir ke } 1= \\
65
\end{array}}{65-\frac{(270)^{2}}{65}}
\end{aligned}
$$

Berdasarkan perhitungan diatas dapat diketahui bahwa nilai varian butiran untuk pernyataan No.1 yang diberikan kepada responden sebesar 0,407 .

$$
\text { 2) } S i=\frac{\Sigma X i^{2}-\frac{\mathbb{E} X i^{2}}{n}}{n}
$$

Contoh butir ke $2=\frac{1314-\frac{290^{2}}{65}}{65}$ $=0,310$

3) $S i=\frac{\Sigma X i^{2}-\frac{\mathbb{C} X 0^{2}}{n}}{n}$

Contoh butir ke $3=$

$$
\begin{aligned}
& \frac{1108-\frac{260^{2}}{65}}{65} \\
& =1,045
\end{aligned}
$$

4) $S i=\frac{\Sigma X i^{2}-\frac{\mathbb{C} X 0^{2}}{n}}{n}$

Contoh butir ke $4=$ $\underline{1216-\frac{278^{2}}{65}}$

$$
=0,415
$$

5) $S i=\frac{\Sigma X i^{2}-\frac{\mathbb{C} X D^{2}}{n}}{n}$
Contoh butir ke $5=$ $1181-\frac{273^{2}}{65}$

65
$=0,529$

6) $S i=\frac{\Sigma i^{2}-\frac{\mathbb{C} X D^{2}}{n}}{n}$

Contoh butir ke $6=$ $\underline{1330-\frac{292^{2}}{65}}$

$=0,285$

7) $S i=\frac{\Sigma X i^{2}-\frac{\mathbb{C} X 0^{z}}{n}}{n}$

Contoh butir ke $7=$ $\frac{971-\frac{245^{2}}{65}}{65}$ $=0,731$

8) $S i=\frac{\Sigma X i^{2}-\frac{\mathbb{C} X D^{x}}{n}}{n}$

Contoh butir ke $8=$ 944- $\frac{240^{2}}{65}$

$$
65
$$

$=0,889$

9) $S i=\frac{\Sigma X i^{2}-\frac{\mathbb{C} X 0^{z}}{n}}{n}$

Contoh butir ke $9=$ $\underline{920-\frac{234^{2}}{65}}$

$=1,19$

10) $S i=\frac{\Sigma X i^{2}-\frac{\mathbb{Q} X 0^{2}}{n}}{n}$

Contoh butir ke $10=$ $\underline{1173-\frac{273^{2}}{65}}$ 


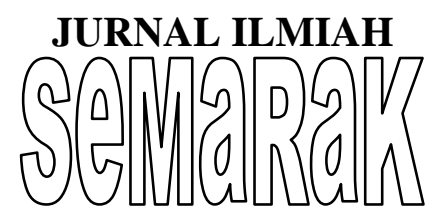

$=0,406$

1) Menghitung jumlah Varians skor butir pernyataan :

$$
\begin{aligned}
\Sigma \mathrm{Si}= & \mathrm{Si} 1+\mathrm{Si} 2+\mathrm{Si} 3+ \\
& \mathrm{Si} 4+\mathrm{Si} 5+\mathrm{Si} 6+ \\
& \mathrm{Si} 7+\mathrm{Si} 8+\mathrm{Si} 9+
\end{aligned}
$$

Tabel 4.13 Perhitungan Uji Reliabilitas Variabel Produktivitas Kerja (Y)

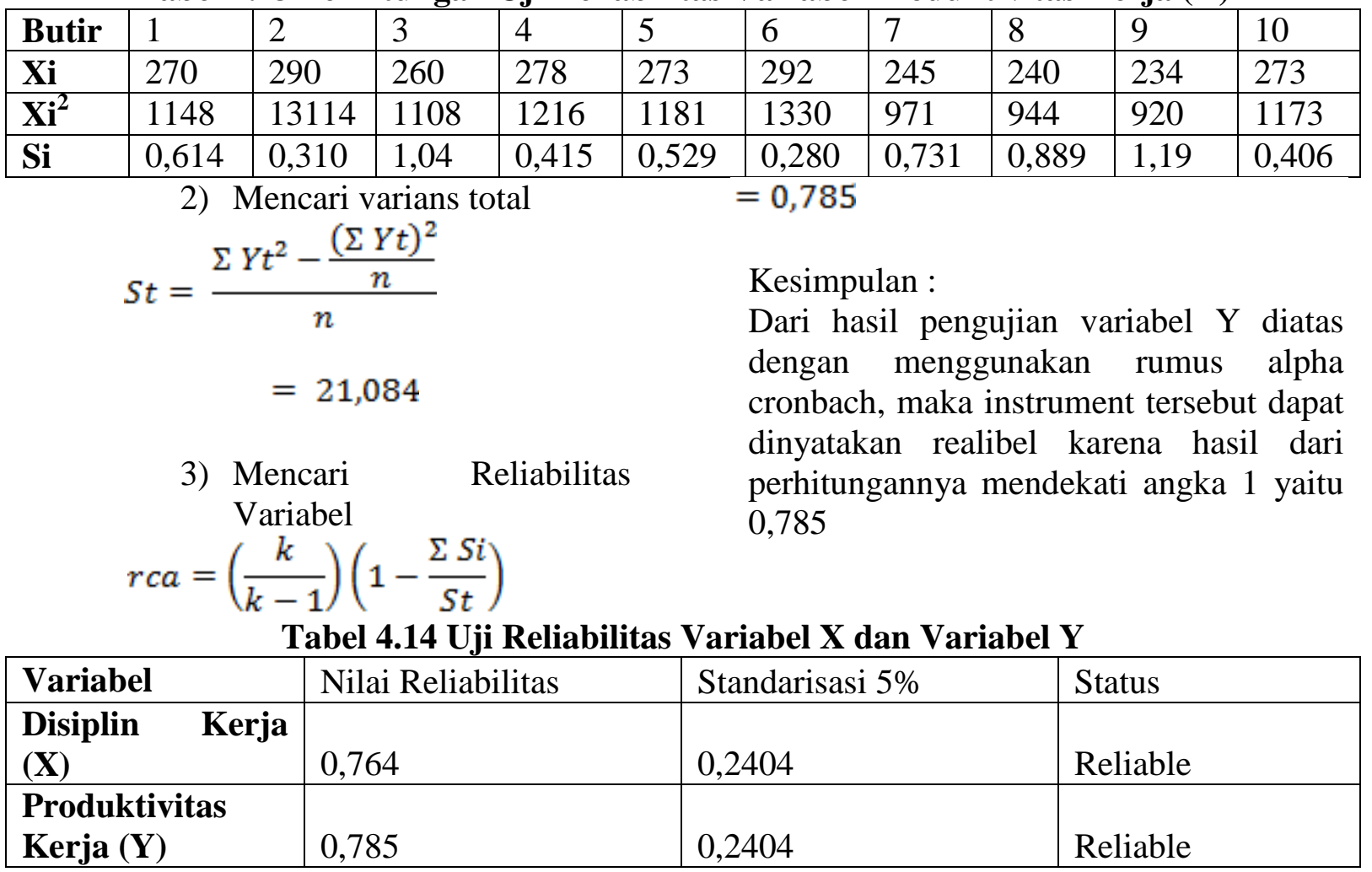

\section{Korelasi Product Moment}

Dalam menganalisa pengaruh disiplin kerja terhadap Produktivitas Kerja Karyawan pada PT Telkom Legok.Penulis menggunakan metode korelasi sederhana.
Dari hasil pengumpulan kuesioner sebanyak 65 responden dengan kuesioner disiplin kerja $(\mathrm{X})$ dan produktivitas $(\mathrm{Y})$ sebanyak 10 pertanyaan dan diperoleh data sebagai berikut:

Tabel 4.15 Analisa Pengaruh Disiplin Kerja terhadap Produktivitas Kerja Karyawan

\begin{tabular}{|l|l|l|l|l|l|}
\hline NO & $\mathbf{X}$ & $\mathbf{Y}$ & $\mathbf{X}^{\mathbf{2}}$ & $\mathbf{Y}^{\mathbf{2}}$ & $\mathbf{X Y}$ \\
\hline 1 & 49 & 50 & 2401 & 2500 & 2450 \\
\hline 2 & 43 & 48 & 1849 & 2304 & 2064 \\
\hline 3 & 44 & 39 & 1936 & 1521 & 1716 \\
\hline 4 & 36 & 34 & 1296 & 1156 & 1224 \\
\hline 5 & 42 & 42 & 1764 & 1764 & 1764 \\
\hline 6 & 43 & 43 & 1849 & 1849 & 1849 \\
\hline
\end{tabular}


JURNAL ILMIAH

Samingan o) 5 U
P-ISSN 2615-6849

Jurnal Semarak,Vol. 1,No.1,Februari 2018 , Hal (92-107)

@ Prodi Manajemen Fakultas Ekonomi Universitas Pamulang

\begin{tabular}{|c|c|c|c|c|c|}
\hline NO & $\mathbf{X}$ & $\mathbf{Y}$ & $\mathbf{X}^{2}$ & $\mathbf{Y}^{2}$ & XY \\
\hline 7 & 47 & 43 & 2209 & 1849 & 2021 \\
\hline 8 & 35 & 35 & 1225 & 1225 & 1225 \\
\hline 9 & 39 & 38 & 1521 & 1444 & 1482 \\
\hline 10 & 42 & 45 & 1764 & 2025 & 1890 \\
\hline 11 & 42 & 42 & 1764 & 1764 & 1764 \\
\hline 12 & 42 & 44 & 1764 & 1936 & 1848 \\
\hline 13 & 42 & 40 & 1764 & 1600 & 1680 \\
\hline 14 & 39 & 40 & 1521 & 1600 & 1560 \\
\hline 15 & 33 & 35 & 1089 & 1225 & 1155 \\
\hline 16 & 50 & 50 & 2500 & 2500 & 2500 \\
\hline 17 & 35 & 32 & 1225 & 1024 & 1120 \\
\hline 18 & 38 & 34 & 1444 & 1156 & 1292 \\
\hline 19 & 38 & 37 & 1444 & 1369 & 1406 \\
\hline 20 & 38 & 37 & 1444 & 1369 & 1406 \\
\hline 21 & 38 & 36 & 1444 & 1296 & 1368 \\
\hline 22 & 44 & 38 & 1936 & 1444 & 1672 \\
\hline 23 & 41 & 41 & 1681 & 1681 & 1681 \\
\hline 24 & 40 & 39 & 1600 & 1521 & 1560 \\
\hline 25 & 35 & 36 & 1225 & 1296 & 1260 \\
\hline 26 & 37 & 35 & 1369 & 1225 & 1295 \\
\hline 27 & 48 & 40 & 2304 & 1600 & 1920 \\
\hline 28 & 40 & 41 & 1600 & 1681 & 1640 \\
\hline 29 & 41 & 40 & 1681 & 1600 & 1640 \\
\hline 30 & 46 & 41 & 2116 & 1681 & 1886 \\
\hline 31 & 41 & 41 & 1681 & 1681 & 1681 \\
\hline 32 & 40 & 41 & 1600 & 1681 & 1640 \\
\hline 33 & 40 & 40 & 1600 & 1600 & 1600 \\
\hline 34 & 41 & 44 & 1681 & 1936 & 1804 \\
\hline 35 & 39 & 36 & 1521 & 1296 & 1404 \\
\hline 36 & 42 & 42 & 1764 & 1764 & 1764 \\
\hline 37 & 41 & 40 & 1681 & 1600 & 1640 \\
\hline 38 & 50 & 50 & 2500 & 2500 & 2500 \\
\hline 39 & 45 & 45 & 2025 & 2025 & 2025 \\
\hline 40 & 45 & 46 & 2025 & 2116 & 2070 \\
\hline 41 & 45 & 47 & 2025 & 2209 & 2115 \\
\hline 42 & 45 & 44 & 2025 & 1936 & 1980 \\
\hline 43 & 46 & 44 & 2116 & 1936 & 2024 \\
\hline 44 & 38 & 38 & 1444 & 1444 & 1444 \\
\hline 45 & 41 & 44 & 1681 & 1936 & 1804 \\
\hline 46 & 47 & 45 & 2209 & 2025 & 2115 \\
\hline 47 & 36 & 37 & 1296 & 1369 & 1332 \\
\hline 48 & 44 & 43 & 1936 & 1849 & 1892 \\
\hline
\end{tabular}




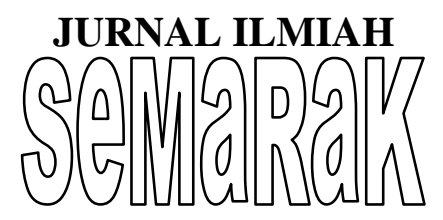

P-ISSN 2615-6849

Jurnal Semarak,Vol. 1,No.1,Februari 2018 , Hal (92-107)

@ Prodi Manajemen Fakultas Ekonomi Universitas Pamulang

\begin{tabular}{|l|l|l|l|l|l|}
\hline NO & $\mathbf{X}$ & $\mathbf{Y}$ & $\mathbf{X}^{\mathbf{2}}$ & $\mathbf{Y}^{\mathbf{2}}$ & $\mathbf{X Y}$ \\
\hline 49 & 37 & 36 & 1369 & 1296 & 1332 \\
\hline 50 & 44 & 43 & 1936 & 1849 & 1892 \\
\hline 51 & 46 & 44 & 2116 & 1936 & 2024 \\
\hline 52 & 38 & 33 & 1444 & 1089 & 1254 \\
\hline 53 & 47 & 44 & 2209 & 1936 & 2068 \\
\hline 54 & 40 & 41 & 1600 & 1681 & 1640 \\
\hline 55 & 33 & 29 & 1089 & 841 & 957 \\
\hline 56 & 40 & 39 & 1600 & 1521 & 1560 \\
\hline 57 & 36 & 44 & 1296 & 1936 & 1584 \\
\hline 58 & 47 & 47 & 2209 & 2209 & 2209 \\
\hline 59 & 41 & 50 & 1681 & 2500 & 2050 \\
\hline 60 & 40 & 40 & 1600 & 1600 & 1600 \\
\hline 61 & 40 & 42 & 1600 & 1764 & 1680 \\
\hline 62 & 28 & 34 & 784 & 1156 & 952 \\
\hline 63 & 44 & 43 & 1936 & 1849 & 1892 \\
\hline 64 & 39 & 39 & 1521 & 1521 & 1521 \\
\hline 65 & 39 & 45 & 1521 & 2025 & 1755 \\
\hline$\sum$ & 2672 & 2655 & 111050 & 109817 & 110142 \\
\hline$D a n$ & & & & &
\end{tabular}

Dari data di atas, penulis gunakan untuk mengetahui hubungan antara variabel $\mathrm{X}$ (disiplin kerja) dengan $\mathrm{Y}$ (produktivitas), dengan menggunakan rumus korelasi sebagai berikut :

$$
\begin{aligned}
& r=\frac{n \sum x y-\left(\sum x\right)(\Sigma y)}{\sqrt{\left(n \Sigma X^{2}-(\Sigma X)^{2}\right\}\left(n \Sigma Y^{2}-(\Sigma Y)^{2}\right\}}} \\
& r=0,777
\end{aligned}
$$

Berdasarkan hasil perhitungan uji koefisien korelasi diatas, didapat hasil 0,777 berarti hubungan antara variabel $\mathrm{X}$ dengan variabel $\mathrm{Y}$ kuat.Maka, untuk mengetahui seberapa besar pengaruh Disiplin Kerja terhadap Produktivitas Kerja Karyawan adalah dengan menggunakan koefisien determinasi.

\section{Regresi Linier Sederhana}

Regresi bertujuan untuk mengetahui arah hubungan antara satu variabel terhadap variabel yang lain. Untuk mengetahui pengaruh disiplin kerja terhadap produktivitas kerja karyawan pada PT.Telkom Aksess Legok.

Adapun untuk mengetahui nilai persamaan hubungan regresi, terlebih dahulu perlu dicari nilai konstanta A dan B dengan rumus sebagai berikut :

$$
\begin{aligned}
a & =\frac{(\Sigma Y)\left(\Sigma X^{2}\right)-(\Sigma X)(\Sigma X Y)}{n\left(\Sigma X^{2}\right)-(\Sigma X)^{2}} \\
& =7,733
\end{aligned}
$$

$$
\begin{aligned}
& b=\frac{n(\Sigma X Y)-(\Sigma X)(\Sigma Y)}{n\left(\Sigma X^{2}\right)-(\Sigma X)^{2}} \\
& =0,827
\end{aligned}
$$

Dengan demikian dapat diperoleh angka persamaan berdasarkan dari output koefisien $\mathrm{Y}=7,733+0,827 \mathrm{X}$ artinya bahwa perubahan $\mathrm{Y}$ searah dengan perubahan X. Jadi nilai Y akan meningkat jika $\mathrm{X}$ meningkat, sebaliknya nilai $\mathrm{Y}$ akan menurun jika $\mathrm{X}$ menurun. Jadi dapat disimpulkan bahwa Disiplin Kerja berpengaruh positif terhadap Produktivitas Kerja karyawan pada PT Telkom Akses Legok. Artinya jika disiplin kerja 


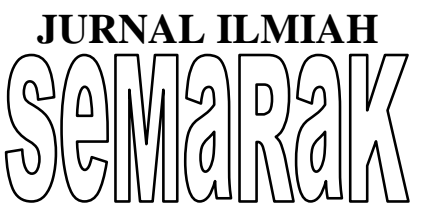

meningkat maka akan meningkatkan produktivitas kerja karyawan, begitu pula sebaliknya. Koefisien regresi $\mathrm{X}=0,827$ maka skor variabel $\mathrm{Y}$ akan bertambah 0,827 satuan jika asumsi konstanta $\mathrm{X}$ ditingkatkan1 satuan. Artinya jika disiplin kerja baik maka akan meningkatkan produktivitas kerja karyawan, begitu pula sebaliknya.

\section{Koefisien Determinasi}

Selanjutnya untuk mengetahui seberapa besar Disiplin kerja terhadap Kinerja digunakan rumus koefisien penentu atau koefisien Determinasi sebagai berikut :

$$
K d=r^{2} \times 100 \%
$$

$=(0,777)^{2} \times 100 \%$

$=60,3 \%$

Berdasarkan perhitungan koefisien determinasi diatas didapatkan hasil 60,3\%, maka Disiplin kerja mempengaruhi terhadap Produktivitas Kerja Karyawan sebesar $60,3 \%$ dan sisanya sebesar $39,7 \%$ dipengaruhi oleh faktor-faktor lain seperti lingkungan kerja, karena bila pengaturan suasana kerja yang buruk dan lingkungan kerja yang tidak memadai dapat membuat 65 karyawan tidak nyaman dalam bekerja, jika tidak nyaman dalam bekerja maka tidak dapat berkonsentrasi dalam bekerja sehingga kualitas dan kuantitas produk tidak dapat terjaga dengan baik. Sebaliknya, suasana kerja fleksibel membuat karyawan nyaman dalam bekerja dengan beberapa aturan tertentu, dan karyawan dapat bekerja dengan konsentrasi sehingga kualitas dan kuantitas produk dapat terjaga dengan baik.

\section{F. Kesimpulan}

Dari hasil penelitian yang telah dilaksanakan, akhirnya pada bab ini

\section{Uji Hipotesis}

a. Merumuskan hipotesis

Adapun hipotesis yang diajukan dalam penelitian ini adalah sebagaiberikut

$\mathrm{H}_{\mathrm{O}}: \mathrm{r}=0$, Tidak terdapat pengaruh yang positif antara disiplin kerja terhadap produktivitas kerja karyawan pada PT Telkom Aksess Legok

$\mathrm{H}_{\mathrm{a}}: \mathrm{r} \neq 0$, Terdapat pengaruh yang positif antara disiplin kerja terhadap produktivitas kerja karyawan pada PT Telkom Aksess Legok.

Berdasarkan hasil perhitungan diatas, maka penulis melakukan pengujian $\mathrm{Uji} t$ dengan cara membandingkan nilai $t$ table dengan $\mathrm{t}$ hitung. Nilai t table ditentukan berdasarkan tingkat signifikan $(\alpha)$ yang digunakan dan derajat kebebasan $(\mathrm{df}=\mathrm{n}$ 2) yang besarnya tergantung dari jumlah sampel (n). pengujian melalui Uji t pada derajat signifikan 5\% $(\alpha=0.05)$.

\section{b. Uji Signifikasi}

Rumus:

$$
\text { thitung }=\frac{r \sqrt{n-2}}{\sqrt{1-r^{2}}}
$$

$$
=9,788
$$

Jadi, dari hasil perhitungan uji hipotesis diatas maka dapat dilihat bahwa, $\mathrm{t}_{\text {hitung }}>\mathrm{t}_{\text {tabel }}$, atau $9,788>1,669$ maka menunjukan hasil yang signifikan.Atau dengan kata lain $t_{\text {hitung }}>t_{\text {tabel }}$, maka Ho ditolak dan Ha diterima, yang berarti bahwa terdapat pengaruh yang signifikan antara Disiplin Kerja terhadap Produktivitas Kerja Karyawan Pada PT Telkom Aksess Legok

penulisan menerapkan kesimpulan dan hasil penelitian sebagai berikut:

1. Disiplin kerja karyawan PT Telkom Aksess Legok dalam keadaan yang sudah baik. Hal ini 
di buktikan dengan hasil jawaban responden yang mengatakan sangat setuju $36,153 \%$ dan setuju $45,384 \%$ sehingga total yang menjawab sangat setuju dan setuju yaitu $81,537 \%$

2. Produktivitas Kerja Karyawan PT Telkom Aksess Legok dalam keadaan yang sudah cukup baik. Hal ini di buktikan dengan hasil jawaban responden yang mengatakan sangat setuju 32,923\% dan setuju $48,923 \%$ sehingga total yang menjawab sangat setuju dan setuju yaitu $81,846 \%$.

3. $\mathrm{Y}=7,733+0,827 \mathrm{X}, \mathrm{r}=0,777, \mathrm{KD}$ $=60,3 \%$ dan sisanya $39,7 \%$, Uji t dan $t_{\text {hitung }} 9,788 \geq t_{\text {tabel }} 1,669$, maka menunjukkan hasil yang signifikan atau dengan kata lain $t_{\text {hitung }} \geq t_{\text {tabel }}$ yaitu Ho ditolak dan Ha diterima yang berarti bahwa terdapat pengaruh yang signifikan antara disiplin kerja terhadap produktivitas kerja karyawan pada PT Telkom Akses Legok.

\section{Daftar Pustaka}

Handoko, T. Hani. 2012. Manajemen Personalia dan Sumber Daya Manusia. Yogyakarta: BPFE.
Hasibuan, Malayu S.P. 2013. Manajemen Sumber Daya Manusia Jakarta: PT Bumi Aksara.

Mangkunegara, Prabu Anwar, 2009. Evaluasi Kinerja Sumber Daya Manusia,Bandung: PT. Rafika Aditama.

Mangkunegara, A.A Anwar Prabu. 2011. Evaluasi Kinerja Sumber Daya Manusia. Bandung:PT Refika Aditama.

M, Yani. 2012. Manajemen Sumber Daya Manusia. Jakarta: PT Mitra Wacana Media.

Riva'i, Veithzal. 2009. Manajemen Sumber Daya Manusia Untuk Perusahaan dari Teori Ke Praktik. Jakarta: PT Raja Grafindo Persada.

Siagian, P. Sondang. 2009. Manajemen Sumber Daya Manusia. Jakarta: PT Bumi Aksara.

Simamora, Henry. 2014. Manajemen Sumber Daya Manusia edisi 3. Yogyakarta: STIE YKPN.

Sugiyono. 2014. Metode Penelitian Pendidikan Pendekatan Kuantitatif, Kualitatif Dan $R \& D$. Bandung: Alfabeta.

Sutrisno, Edy. 2009. Manajemen Sumber Daya Manusia. Jakarta: PT Kencana Prenada Media Group 